\title{
Media Daring dan Kuantitas Pemberian Tugas Terhadap Kepuasan Belajar Mahasiswa
}

\author{
Juhji $^{* 1}$, Moch. Syamsuri Rachman ${ }^{* 2}$, Nurjaya ${ }^{* 3}$

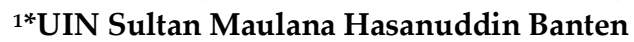 \\ ${ }^{2 *}$ STKIP Arrahmaniyah, Depok \\ ${ }^{3 *}$ Universitas Pamulang \\ Email: juhji@uinbanten.ac.id ${ }^{* 1}$,syamrachman21@gmail.com ${ }^{* 2}$, \\ dosen01605@unpam.ac.id ${ }^{* 3}$
}

\begin{abstract}
The research aims to analyze the influence of online media and the number of lecture assignments on the learning satisfaction of Islamic Education students. The research method uses ex-post facto, conducted on 138 Islamic Religious Education students in the academic year 2019/2020. The data is retrieved through a Google Form that is distributed to all students. Validity and reliability tests are carried out on research instruments. Normality and Homogeneity testing is performed as a prerequisite for further tests. The data is analyzed through the help of SPSS 16.0. The results showed that the number of assignments and online media simultaneously proved not to affect student learning satisfaction. Other factors affect student learning satisfaction. This research recommends that further research be conducted related to student learning satisfaction.
\end{abstract}

Keywords: Online Media, College Assignments, Student Learning Satisfaction

\begin{abstract}
Abstrak
Penelitian bertujuan untuk menganalisis pengaruh media daring dan kuantitas pemberian tugas kuliah terhadap kepuasan belajar mahasiswa Pendidikan Agama Islam. Metode penelitian menggunakan ex-post facto, dilakukan pada 138 mahasiswa Pendidikan Agama Islam tahun akademik 2019/2020. Data diambil melalui Google Form yang disebarkan ke semua mahasiswa. Uji validitas dan reliabilitas dilakukan pada instrumen
\end{abstract}


penelitian. Pengujian Normalitas dan Homogenitas dilakukan sebagai prasyarat uji lanjut. Data dianalisa melalui bantuan SPSS 16.0. Hasil analisa menunjukkan bahwa kuantitas pemberian tugas dan media daring secara simultan terbukti tidak mempengaruhi kepuasan belajar mahasiswa. Ada faktor-faktor lain yang mempengaruhi kepuasan belajar mahasiswa. Penelitian ini merekomendasikan untuk dilakukan penelitian lanjut terkait kepuasan belajar mahasiswa.

Kata Kunci: Media Daring, Pemberian Tugas Kuliah, Kepuasan Belajar Mahasiswa

\section{Pendahuluan}

Kualitas pendidikan di perguruan tinggi dapat dicapai melalui penerapan proses pembelajaran secara baik ${ }^{1}$ dengan berbagai model, pendekatan, strategi, dan metode yang digunakan Dosen secara tepat. Pembelajaran dapat dipahami sebagai proses internalisasi ilmu ke dalam bagan pebelajar. ${ }^{2}$ Dalam hal ini, pembelajaran merupakan proses kegiatan yang dilakukan Dosen kepada para mahasiswanya agar pesan ilmu pengetahuan dapat diterima secara baik dengan tujuan memperoleh hasil belajar secara berkualitas dan bermutu.

Keberhasilan suatu perguruan tinggi ditentukan oleh kualitas layanan pembelajaran ${ }^{3}$ yang diberikan Dosen kepada para mahasiswanya, dimana layanan pembelajaran berkualitas dapat dilihat dari tingkat kepuasan belajar mahasiswanya. Terciptanya kepuasan mahasiswa melalui proses pembelajaran merupakan salah

${ }^{1}$ Marus Suti, 'Strategi Peningkatan Mutu Di Era Otonomi Pendidikan', Jurnal Medtek 3, no. 2 (2011): 1-6.

2 Albitar Septian Syarifudin, 'Impelementasi Pembelajaran Daring Untuk Meningkatkan Mutu Pendidikan Sebagai Dampak Diterapkannya Social Distancing', Jurnal Pendidikan Bahasa Dan Sastra Indonesia Metalingua 5, no. 1 (2020): 31-34; Juhji Juhji, Profesi Pendidik Dan Tenaga Kependidikan (Serang: Pusat Penelitian dan Penerbitan LP2M IAIN Sultan Maulana Hasanuddin Banten, 2017).

3 Lianna Sugandi, 'Pengaruh Teknologi Informasi Untuk Meningkatkan Pelayanan Dalam Proses Belajar Mengajar', ComTech: Computer, Mathematics and Engineering Applications 5, no. 2 (2014): 939-53; Riza Bahtiar Sulistyan, Hafid Aditya Pradesa, and Kasno Kasim, 'Peran Mediasi Kepuasan Dalam Pengaruh Kualitas Pelayanan Dan Citra Institusi Terhadap Retensi Mahasiswa (Studi Pada Mahasiswa Perguruan Tinggi Di Lumajang)', WIGA-Jurnal Penelitian Ilmu Ekonomi 7, no. 2 (2017): 77-87. 
satu tujuan yang harus dicapai Dosen dalam melakukan proses pembelajaran karena ia merupakan salah satu penentu keberhasilan belajar mahasiswa di perguruan tinggi. Dengan demikian, Dosen harus mampu meningkatkan mutu layanan pembelajaran terutama di masa pandemi covid 19, dimulai dari melakukan analisa terhadap kebutuhan mahasiswa akan layanan akademik dan bermuara pada persepsi mereka terhadap mutu layanan yang diberikan Dosen sehingga menimbulkan rasa puas dalam belajar mereka.

Orang yang memiliki rasa puas akan tergambar pada raut mukannya yang berseri, terlihat tidak ada beban, dan selalu ceria. Sebaliknya, orang yang tidak merasa puas akan tergambarkan dengan rasa gelisah, jengkel, dan kadang terlihat emosinya yang labil. ${ }^{4}$ Menurut Syurya dalam buku Psikologi Pembelajaran dan Pengajaran disebutkan bahwa kepuasan belajar memiliki ciri-ciri: (1) adanya imbalan hasil belajar (umpan balik), (2) adanya rasa aman dalam belajar, (3) kondisi belajar yang memadai, (4) adanya kesempatan untuk mengembangkan diri, (5) adanya hubungan yang baik, (6) pekerjaan itu menarik, (7) penuh tantangan, (8) adanya penghargaan, dan (9) adanya tanggung jawab. ${ }^{5}$

Jika mahasiswa sudah merasa puas dalam mengikuti proses kegiatan pembelajaran yang dilakukan Dosen di perguruan tinggi, maka diharapkan ia memiliki motivasi belajar yang tinggi. Motivasi belajar mahasiswa dapat terlihat dari sikap dan perilakunya dalam kegiatan pembelajaran. Mahasiswa yang memiliki motivasi tinggi akan menampakkan kesungguhannya dalam belajar termasuk dalam menngerjakan tugas-tugas yang diberikan oleh Dosen. Adanya motivasi yang tinggi mendorong semangat belajar yang tinggi pula, begitu juga sebaliknya motivasi rendah akan melemahkan semangat belajar mahasiswa. Oleh karena itu, dibutuhkan upaya bagaimana menumbuhkan motivasi belajar mahasiswa di tengah pembelajaran daring selama wabah covid 19 yang telah memaksa mereka untuk belajar di rumah dengan sistem daring bukan luring. Salah satu upaya

${ }^{4}$ Ekwanis Putrielis, ‘Keterkaitan Penggunaan Moving Class Dengan Motivasi Belajar Dan Dampaknya Terhadap Kepuasan Belajar Ekonomi Siswa Man 2 Model Pekanbaru', PEKBIS (Jurnal Pendidikan Ekonomi Dan Bisnis) 9, no. 2 (2017): 125-39.

${ }_{5}$ M Surya, Psikologi Pembelajaran Dan Pengajaran (Bandung: Pustaka Bani Quraisy, 2014). 
menumbuhkan motivasi belajar mahasiswa dapat dilakukan dengan menumbuhkan rasa kepuasan belajar mereka.

Hasil penelitian Rahmawati melaporkan bahwa faktor-faktor yang mempengaruhi tingkat kepuasan mahasiswa didasarkan atas faktor yang berhubungan dengan produk perguruan tinggi (seperti kurikulum, biaya pendidikan, fasilitas yang ditawarkan, dan pemenuhan hak mahasiswa), pelayanan yang diberikan (seperti respon terhadap pemecahan masalah yang dimiliki mahasiswa yang berkaitan dengan akademik), profesionalisme dosen (seperti kemudahan dan kenyamanan mahasiswa dalam mengikuti proses perkuliahan). ${ }^{6}$ Dengan demikian lembaga, pelayanan, dan profesionalisme dosen menjadi faktor penentu terhadap kepuasan mahasiswa.

Kepuasan belajar dapat dipahami sebagai persepsi seorang individu atas manfaat dari sesuatu (usefulness), menyenangkan (enjoyed), membantu (helpful), dan mudah untuk dipelajari (easy to learn) dalam memahami sesuatu ${ }^{7}$ sebagai akibat dari proses pembelajaran yang dilakukan. Menurut Colquitt, Jeffery, dan Michael bahwa bahwa kepuasan kerja sama artinya dengan memiliki perasaan menyenangkan yang didapat dari pengalaman kerja. ${ }^{8}$ Dari pengertian tersebut dapat dinyatakan bahwa kepuasan belajar adalah perspesi seseorang dalam proses pembelajaran yang dilakukan baik secara luring maupun daring.

Pembelajaran dalam jaringan (disingkat daring) adalah proses pembelajaran yang dilaksanakan oleh pengguna dengan

${ }^{6}$ Diana Rahmawati, 'Analisis Faktor-Faktor Yang Mempengaruhi Kepuasan Mahasiswa', Jurnal Economia 9, no. 1 (2013): 52-65.

7 Pigo Nauli, 'Perbandingan Metoda Pembelajaran Akuntansi Pengantar Antara Metoda Konvensional Dan Metoda Berbasis Matematika Terhadap Prestasi Dan Kepuasan Belajar', Simposium Nasional Akuntansi XIV Aceh, 2011; M. Zineldin, H. C. Akdag, and V. Vasicheva, 'Assessing Quality in Higher Education: New Criteria for Evaluating Students' Satisfaction', Quality in Higher Education 17, no. 2 (2011): 231-43; M. Biasutti and E. D. Heba, 'Using Wiki in Teacher Education: Impact on Knowledge Management Processes and Student Satisfaction', Computers \& Education 59, no. 3 (2012): 861-72; Evelien Opdecam and Patricia Everaert, 'Improving Student Satisfaction in a First-Year Undergraduate Accounting Course by Team Learning', Issues in Accounting Education 27, no. 1 (2012): 53-82.

8 Jason Colquitt et al., Organizational Behavior: Improving Performance and Commitment in the Workplace, vol. 375 (McGraw-Hill Irwin New York, NY, 2011). 
menggunakan fasilitas jaringan internet sebagai media dalam mentransfer ilmu pengetahuan, ${ }^{9}$ seperti Google Classrom, Whatsapp Group, Zoom, Moodle, Youtube, Edmodo, Google Meet, dan lain-lain. Pembelajaran daring di Indonesia sudah lama dikenal, namun ketenarannya semakin dirasakan pebelajar setelah Pemerintah memberlakukan aturan pembatasan sosial (social distancing) di masa pandemic covid 19, dimana proses pembelajaran di madrasah atau sekolah dan perguruan tinggi diwajibkan dilakukan di rumah dengan bimbingan orang tua, meskipun pelaksanaannya lebih cenderung pada bentuk penugasan melalui aplikasi.

Pemberian tugas kuliah dapat diartikan sebagai pemberian tugas mata kuliah yang diberikan Dosen kepada para mahasiswanya sebagai bentuk umpan balik atas proses pembelajaran yang dilakukannya. Sedangkan kuantitas dapat diartikan sebagai jumlah atau banyak. Dengan demikian, kuantitas pemberian tugas kuliah dapat diartikan sebagai banyaknya pemberian tugas mata kuliah yang diberikan Dosen kepada para mahasiswanya sebagai bentuk umpan balik dan sekaligus sebagai penilaian (assessment) atas proses pembelajaran yang dilakukan.

Hasil penelitian Hakim dan Mulyapradana melaporkan bahwa penggunaan media daring dan motivasi belajar mempunyai nilai positif bagi kepuasan mahasiswa. ${ }^{10}$ Dalam laporannya disimpulkan bahwa penggunaan media daring mempunyai pengaruh terhadap kepuasan mahasiswa dan motivasi belajar tidak terlalu berpengaruh terhadap kepuasan mahasiswa. Lain halnya dengan Susanto bahwa kualitas pelayanan berpengaruh tingkat kepuasan mahasiswa, ${ }^{11}$ artinya semakin tinggi kualitas pelayanan maka semakin tinggi pula tingkat kepuasan mahasiswa. Dari penelitian ini belum ditemukan adanya pengaruh media daring dan kuantitas pemberian tugas terhadap kepuasan belajar mahasiswa.

9 Syarifudin, 'Impelementasi Pembelajaran Daring Untuk Meningkatkan Mutu Pendidikan Sebagai Dampak Diterapkannya Social Distancing'.

10 Mujibul Hakim and Aria Mulyapradana, ‘Pengaruh Penggunaan Media Daring Dan Motivasi Belajar Terhadap Kepuasan Mahasiswa Pada Saat Pandemik Covid-19', Widya Cipta: Jurnal Sekretari Dan Manajemen 4, no. 2 (2020): 154-60.

${ }^{11}$ H Susanto, 'Pengaruh Layanan Akademik Terhadap Kepuasan Mahasiswa Program Pascasarjana Universitas Terbuka Pada Unit Program Belajar Jarak Jauh (UPBJJ) Mataram', Jurnal Pendidikan Terbuka Dan Jarak Jauh 15, no. 2 (2014): 88-98. 
Berdasarkan penjelasan di atas, peneliti menganalisis kepuasan belajar mahasiswa Pendidikan Agama Islam dengan menggunakan variabel-variabel pembelajaran daring dan kuantitas pemberian tugas kuliah dan tujuan menganalisis pengaruh media daring dan kuantitas pemberian tugas kuliah terhadap kepuasan belajar mahasiswa. Melalui tujuan penelitian ini, diharapkan bahwa penelitian ini dapat memberikan jawaban untuk faktor-faktor yang mempengaruhi kepuasan belajar mahasiswa di masa pandemic covid 19.

\section{Hasil dan Pembahasan}

Profil demografi sampel pada penelitian ini dapat dilihat pada tabel 1 di bawah ini.

Tabel 1 Profil Demografi Sampel

\begin{tabular}{|c|c|c|c|}
\hline \multicolumn{2}{|c|}{ Karakteristik Demografi } & \multirow{2}{*}{$\begin{array}{r}\text { Frekuensi } \\
18\end{array}$} & \multirow{2}{*}{$\begin{array}{r}\text { Persen } \\
13.0\end{array}$} \\
\hline Gender & Laki-laki & & \\
\hline & Perempuan & 120 & 87.0 \\
\hline \multirow[t]{5}{*}{ Usia } & 17 tahun & 2 & 1.4 \\
\hline & 18 tahun & 24 & 17.4 \\
\hline & 19 tahun & 81 & 58.7 \\
\hline & 20 tahun & 28 & 20.3 \\
\hline & 21 tahun & 3 & 2.2 \\
\hline \multirow[t]{3}{*}{ Kuantitas Pemberian Tugas } & Tidak Pernah & 4 & 2.9 \\
\hline & Kadang-kadang & 92 & 66.7 \\
\hline & Setiap pertemuan & 42 & 30.4 \\
\hline \multirow[t]{2}{*}{ Media Daring } & Whatsapp Group & 130 & 94.2 \\
\hline & Google Classroom & 8 & 5.8 \\
\hline \multirow[t]{2}{*}{$\begin{array}{l}\text { Kepuasan Belajar Mahasiswa } \\
\text { PAI }\end{array}$} & Puas & 77 & 55.8 \\
\hline & Tidak Puas & 61 & 44.2 \\
\hline
\end{tabular}

$\mathrm{N}=138$ mahasiswa

Berdasarkan Tabel 1 di atas terlihat bahwa sampel penelitian yang diteliti sejumlah 138 orang mahasiswa yang terdiri atas laki-laki sebanyak 18 orang (13\%) dan perempuan sebanyak 120 (87\%). Sampel didominasi oleh perempuan karena mahasiswa Program Studi Pendidikan Agama Islam UIN Sultan Mulana Hasanuddin Banten mayoritas adalah perempuan. Variasi usia responden terlihat pada rentang 17 sampai 21 tahun, dengan rincian responden yang berusia 
17 tahun sebanyak 2 orang (1.4\%), usia 18 tahun sebanyak 24 orang (17.4\%, usia 19 tahun sebanyak 81 orang (58.7), usia 20 tahun sebanyak 28 orang $(20.3 \%)$, dan responden yang berusia 21 tahun sebanyak 3 orang (2.2\%). Frekuensi usia terbanyak (modus) berada pada usia 19 tahun $(58.7 \%)$ dan frekuensi usia terendah berada pada usia 17 tahun $(1.4 \%)$.

Sedangkan data kuantitas pemberian tugas dibedakan menjadi tiga skala yakni tidak pernah, kadang-kadang, dan setiap pertemuan. Pilihan kadang-kadang (66.7\%) menjadi frekuensi tertinggi (modus) pada pemberian tugas Dosen kepada mahasiswa, disusul kemudian bahwa Dosen memberikan tugas mata kuliah di setiap pertemuan (30.4\%), sedangkan 2.9\% (4 responden) menyatakan bahwa Dosen tidak pernah memberikan tugas mata kuliah. Terdapat keunikan pada jawaban tersebut, bahwa 4 responden menyatakan bahwa Dosen tidak pernah memberikan tugas mata kuliah tentu ini disebabkan karena responden tidak mengetahui adanya tugas mata kuliah yang diberikan Dosen kepada mahasiswa, sementara yang lainnya menyatakan adanya tugas mata kuliah yang diberikan.

Media daring yang efektif dan sering digunakan pada pembelajaran online mahasiswa adalah Whatsapp Group sebesar 94.2\%, sedangkan sebagian kecial menggunakan Google Classroom sebesar $5.8 \%$. Penggunaan Whatsapp Group menjadi trend di kalangan proses pembelajaran daring karena hampir semua mahasiswa memiliki aplikasi tersebut. Selain itu, penggunaan Whatsapp Group dipandang lebih efektif dan efisien dalam proses kegiatan pembelajaran secara daring. Sebagaimana hasil penelitian Yensy, Siregar, dkk., Isrofiyah, Kheryadi, dan Surani, dkk., yang menemukan adanya efektivitas pengunaan Whatsapp Group dalam kegiatan pembelajaran.

Hasil kuesioner yang ditampilkan pada Tabel 1 di atas menunjukkan bahwa 55.8\% (sebanyak 77 orang) mahasiswa memiliki kepuasan terhadap aktivitas belajar di Program Studi Pendidikan Agama Islam, sementara 44.2\% (sebanyak 61 orang) lainnya menyatakan bahwa mereka tidak puas terhadap aktivitas belajar mereka. Kepuasan dan ketidakpuasan responden dalam memilih tentu memiliki alasan-alasan tersendiri. Berikut disajikan tabel kepuasan belajar mahasiswa Pendidikan Agama Islam berdasarkan gender. 


\section{Tabel 2 Kepuasan Belajar Mahasiswa PAI Berdasarkan Gender}

\begin{tabular}{|c|c|c|c|c|c|}
\hline & & & \multicolumn{2}{|c|}{$\begin{array}{l}\text { Kepuasan Belajar } \\
\text { Mahasiswa PAI }\end{array}$} & \multirow[b]{3}{*}{ Total } \\
\hline & & & & Tidak & \\
\hline & & & Puas & Puas & \\
\hline \multirow{6}{*}{$\begin{array}{l}\text { Jenis } \\
\text { Kelamin }\end{array}$} & Laki-laki & Count & 7 & 11 & 18 \\
\hline & & $\%$ within Jenis Kelamin & $38.9 \%$ & $61.1 \%$ & $100.0 \%$ \\
\hline & & $\begin{array}{l}\text { \% within Kepuasan Belajar } \\
\text { Mahasiswa PAI }\end{array}$ & $9.1 \%$ & $18.0 \%$ & $13.0 \%$ \\
\hline & Perempuan & Count & 70 & 50 & 120 \\
\hline & & $\%$ within Jenis Kelamin & $58.3 \%$ & $41.7 \%$ & $100.0 \%$ \\
\hline & & $\begin{array}{l}\text { \% within Kepuasan Belajar } \\
\text { Mahasiswa PAI }\end{array}$ & $90.9 \%$ & $82.0 \%$ & $87.0 \%$ \\
\hline \multirow[t]{3}{*}{ Total } & & Count & 77 & 61 & 138 \\
\hline & & $\%$ within Jenis Kelamin & $55.8 \%$ & $44.2 \%$ & $100.0 \%$ \\
\hline & & $\begin{array}{l}\text { \% within Kepuasan Belajar } \\
\text { Mahasiswa PAI }\end{array}$ & $100.0 \%$ & $100.0 \%$ & $100.0 \%$ \\
\hline
\end{tabular}

Berdasarkan perhitungan statistik sebagaimana tertera pada Tabel 2 di atas, menggambarkan kepuasan belajar mahasiswa PAI berdasarkan gender. Terlihat bahwa responden berjenis kelamin lakilaki memiliki tingkat persentase kepuasan belajar sebesar 9.1\% (7 responden) dan $18.0 \%$ (11 responden) menyatakan tidak puas. Sedangkan responden berjenis kelamin perempuan menyatakan bahwa mereka memiliki kepuasan belajar PAI sebesar $90.9 \%$ (70 responden) dan $82.0 \%$ (50 responden) menyatakan bahwa mereka tidak puas terhadap aktivitas belajar Pendidikan Agama Islam. Adanya perbedaannya yang kontras antara jawaban responden lakilaki dengan perempuan dikarenakan jumlah mahasiswa di Program Studi tersebut lebih banyak perempuan dibanding laki-laki.

Uji regresi terhadap ketiga variabel (kepuasan belajar mahasiswa PAI, pembelajaran daring, dan kuantitas pemberian tugas kuliah) melalui SPSS 16.0 dapat dilihat pada Tabel 3 berikut ini.

\section{Tabel 3 Hasil Uji Regresi}




\begin{tabular}{lrrrrr}
\hline Model & R & R Square & $\begin{array}{c}\text { Adjusted R } \\
\text { Square }\end{array}$ & $\begin{array}{l}\text { Std. Error of } \\
\text { the Estimate }\end{array}$ & Durbin-Watson \\
\hline 1 & $.031^{\mathrm{a}}$ & .001 & -.014 & 4.974 & 1.737 \\
\hline
\end{tabular}

a. Predictors: (Constant), Media Daring, Kuantitas Pemberian Tugas

b. Dependent Variable: Kepuasan Belajar Mahasiswa PAI

Berdasarkan Tabel 3 di atas, dapat dilihat bahwa hubungan antara media daring dan kuantitas pemberian tugas kuliah dengan kepuasan belajar mahasiswa PAI adalah sebesar 0.031 dengan koefisien determinasi -0.014, sehingga dapat dinyatakan bahwa kepuasan belajar mahasiswa PAI tidak dapat dijelaskan oleh media daring dan kuantitas pemberian tugas kuliah. Dengan demikian, kepuasan belajar mahasiswa dapat dijelaskan oleh faktor-faktor lain selain faktor media daring dan kuantitas pemberian tugas.

\section{Tabel 4 Persamaan Regresi}

\begin{tabular}{|c|c|c|c|c|c|c|c|}
\hline \multirow[b]{2}{*}{ Model } & \multicolumn{2}{|c|}{$\begin{array}{c}\text { Unstandardized } \\
\text { Coefficients }\end{array}$} & $\begin{array}{c}\text { Standar } \\
\text { dized } \\
\text { Coeffici } \\
\text { ents }\end{array}$ & \multirow[b]{2}{*}{$\mathrm{t}$} & \multirow[b]{2}{*}{ Sig. } & \multicolumn{2}{|c|}{$\begin{array}{l}\text { Collinearity } \\
\text { Statistics }\end{array}$} \\
\hline & B & $\begin{array}{l}\text { Std. } \\
\text { Error }\end{array}$ & Beta & & & $\begin{array}{c}\text { Tolera } \\
\text { nce }\end{array}$ & VIF \\
\hline 1 (Constant) & 43.025 & 2.747 & & 15.660 & .000 & & \\
\hline $\begin{array}{l}\text { Kuantitas } \\
\text { Pemberian Tugas }\end{array}$ & .027 & .834 & .003 & .032 & .975 & 1.000 & 1.000 \\
\hline Media Daring & .645 & 1.812 & .031 & .356 & .722 & 1.000 & 1.000 \\
\hline
\end{tabular}

a. Dependent Variable: Kepuasan Belajar Mahasiswa PAI

Berdasarkan Tabel 4 di atas, terlihat bahwa persamaan regresi kepuasan belajar mahasiswa PAI $=43.025+0.027$ (Kuantitas Pemberian Tugas) + 0.645 (Media Daring) memiliki makna bahwa konstanta sebesar 43 (pembulatan) memiliki arti bahwa tanpa adanya kuantitas pemberian tugas dan media daring, maka kepuasan belajar mahasiswa PAI sebesar 43. Jika variabel kuantitas pemberian tugas naik makan akan menyebabkan kenaikan pada kepuasan belajar mahasiswa sebesar 0.027. Sedangkan jika media daring naik maka 
akan menyebabkan kenaikan pada Kepuasan Belajar Mahasiswa PAI sebesar 0.645 .

Uji hipotesis simpultan terhadap ketiga variabel (kepuasan belajar mahasiswa PAI, kuantitas pemberian tugas, dan media daring) dapat dinyatakan sebagai berikut: Ho: Tidak ada pengaruh kuantitas pemberian tugas dan media daring terhadap kepuasan belajar mahasiswa PAI; dan Ha: Ada pengaruh kuantitas pemberian tugas dan media daring terhadap kepuasan belajar mahasiswa PAI; dengan keputusan bahwa jika probabilitas $>0.05$ maka Ho diterima sedangkan jika probabilitas < 0.05 maka $H o$ ditolak.

\section{Tabel 5 Uji Simultan}

\begin{tabular}{|ll|r|r|r|r|r|}
\hline \multicolumn{2}{|l|}{ Model } & \multicolumn{1}{|c|}{$\begin{array}{l}\text { Sum of } \\
\text { Squares }\end{array}$} & df & Mean Square & F & \multicolumn{1}{|c|}{ Sig. } \\
\hline 1 & Regression & 3.153 & 2 & 1.576 & .064 & $.938^{\mathrm{a}}$ \\
& Residual & 3339.427 & 135 & 24.736 & & \\
\multicolumn{1}{|l|}{ Total } & 3342.580 & 137 & & & \\
\hline
\end{tabular}

a. Predictors: (Constant), Media Daring, Kuantitas Pemberian Tugas

b. Dependent Variable: Kepuasan Belajar Mahasiswa PAI

Dari hasil analisis pada Tabel 5 di atas, terlihat bahwa probabilitas sebesar 0.938 (>0.05) sehingga Ho diterima. Artinya, kuantitas pemberian tugas dan media daring secara simultan terbukti tidak mempengaruhi kepuasan belajar mahasiswa sehingga hipotesis alternatif $(\mathrm{Ha})$ ditolak. Hasil uji model parsial dengan memperlihatkan nilai probabilitas pada uji t memperoleh nilai t hitung untuk kuantitas pemberian tugas sebesar 0.32 dan media daring sebesar 0.356. Karena probabilitas > 0.05 maka dapat disimpulkan bahwa secara parsial kedua variabel tersebut terbukti tidak berpengaruh secara signifikan terhadap kepuasan belajar mahasiswa PAI.

Media dalam jaringan (daring) yang seringkali digunakan dalam proses pembelajaran kuliah adalah Whatsapp Group. Hal ini disebabkan karena Whatsapp Group dipandang efektif dan efisien 
dalam proses pembelajaran. Sebagaimana hasil temuan Yensy, ${ }^{12}$ Siregar, dkk., ${ }^{13}$ Isrofiyah, ${ }^{14}$ Kheryadi, ${ }^{15}$ dan Surani, dkk., ${ }^{16}$ yang menemukan adanya efektivitas pengunaan Whatsapp Group dalam kegiatan pembelajaran. Selain mudah dan fleksibel, Whatsapp Group juga dilengkapi dengan berbagai fitur seperti gallery, contact, camera, maps, audio, dan document. Hasil survei Indrayani dan Suliworo menunjukkan bahwa hampir $90 \%$ pelajar, mahasiswa dan dosen menggunakan aplikasi Whatsapp dalam aktivitas sehari-hari maupun dalam kegiatan pembelajaran. Ini menunjukkan bahwa Whatsapp Group sangat efektif dan efisien digunakan dalam proses pembelajaran.

Sejalan dengan adanya pandemic covid 19, hampir semua proses pembelajaran dianjurkan dan harus dilakukan di rumah dengan didampingi oleh orang tua, termasuk juga proses pembelajaran mahasiswa di perguruan tinggi dilakukan secara daring. Proses pembelajaran secara daring tentu disesuaikan dengan letak geografis dan kondisi para mahasiswanya. Ada yang melakukan pembelajaran secara virtual melalui Zoom atau Google Meet, namun ada juga yang melakukannya hanya sebatas pemberian tugas saja. Peneliti memberikan kuesioner kepada 138 mahasiswa dengan ajuan pertanyaan: “Seberapa seringkah Dosen memberikan tugas?" Jawaban responden bervariasi, mereka yang menjawab tiap pertemuan sebanyak 30.4\%, menjawab kadang-kadang sebanyak $66.7 \%$ dan menjawab tidak pernah sebanyak $2.9 \%$.

${ }^{12}$ N. A. Yensy, 'Efektifitas Pembelajaran Statistika Matematika Melalui Media Whatsapp Group Ditinjau Dari Hasil Belajar Mahasiswa (Masa Pandemik Covid 19)', Jurnal Pendidikan Matematika Raflesia 5, no. 2 (2020): 65-74.

${ }^{13}$ Rini Kesuma Siregar, Nusaimah Harahap, and Lisa Fitri Meidipa, 'Efektifitas Penggunaan Whatsapp Untuk Mengurangi Prokrastinasi Akademik Mahasiswa Bahasa Inggris Di Universitas Graha Nusantara', Jurnal LPPM 9, no. 3 (2019).

14 Safi' Isrofiyah, 'Efektivitas Penggunaan Media WA (Whatsapp) Pada Pembelajaran Dengan Model Problem Posing Terhadap Motivasi Dan Hasil Belajar Kognitif Dalam Materi Stoikiometri Kelas X.', DISERTASI Dan TESIS Program Pascasarjana UM, 2017.

${ }^{15}$ Kheryadi Kheryadi, "The Implementation of "Whatsapp" as a Media of English Language Teaching', Loquen: English Studies Journal 10, no. 2 (2018): 1-14.

${ }^{16}$ Dewi Surani and A Chaerudin, 'Pemanfaatan Media Whatsapp Grouping Dalam Peningkatan Kemampuan Bahasa Inggris Ekonomi Mahasiswa Fakultas Ekonomi Dan Bisnis', Tarbawi: Jurnal Keilmuan Manajemen Pendidikan 5, no. 02 (2019): $155-72$. 
Pemberian tugas merupakan pekerjaan yang sengaja diberikan Dosen kepada para mahasiswanya yang harus dilaksanakan secara baik sesuai tujuan pembelajaran yang diinginkan. Pemberian tugas merupakan metode yang dapat memberikan kesempatan kepada para mahasiswa untuk melaksanakan tugas mereka berdasarkan petunjuk Dosen secara langsung maupun tidak langsung dan dapat diberikan kepada perorangan maupun kelompok. Pemberian tugas belajar termasuk tugas perkuliahan dipandang sangat penting karena sebagai umpan balik dari proses pembelajaran yang dilakukan Dosen kepada para mahasiswanya. Sebagaimana diungkapkan oleh Sabriani, ${ }^{17}$ serta Seruni dan Hikmah bahwa pemberian tugas penting dilakukan sebagai umpan balik dari sebuah proses pembelajaran.

Kepuasan belajar mahasiswa Pendidikan Agama Islam tidak dipengaruhi oleh variabel media daring dan kuantitas pemberian tugas kuliah. Ini terlihat dari hasil analisa hipotesis penelitian (lihat tabel 3) yang menemukan bahwa hubungan antara media daring dan kuantitas pemberian tugas kuliah dengan kepuasan belajar mahasiswa PAI adalah sebesar 0.031 dengan koefisien determinasi -0.014. Sehingga, kepuasan belajar mahasiswa PAI tidak dapat dijelaskan oleh media daring dan kuantitas pemberian tugas kuliah.

Temuan ini menyimpulkan bahwa kepuasan belajar mahasiswa $(Y)$ secara simultan tidak dapat dijelaskan oleh kedua variabel media daring $\left(\mathrm{X}_{1}\right)$ dan kuantitas pemberian tugas kuliah $\left(\mathrm{X}_{2}\right)$. Terdapat faktor-faktor lain yang dapat mempengaruhi kepuasan belajar mahasiswa. Kepuasan belajar mahasiswa dapat dijelaskan oleh faktor-faktor seperti: profesionalisme dosen, kinerja dosen, kemudahan akses informasi akademik, layanan mengajar, sarana prasarana, dan kenyamanan mereka dalam mengikuti perkulian di kampus..

\section{Kesimpulan}

Temuan penelitian ini menyimpulkan bahwa kepuasan belajar mahasiswa secara simultan tidak dipengaruhi oleh adanya media

${ }^{17}$ Sitti Sabriani, ‘Penerapan Pemberian Tugas Terstruktur Disertai Umpan Balik Pada Pembelajaran Langsung Untuk Meningkatkan Motivasi Dan Hasil Belajar Siswa (Studi Pada Materi Pokok Struktur Atom Kelas X6 SMA Negeri 3 Watampone).', Chemica: Jurnal Ilmiah Kimia Dan Pendidikan Kimia 13, no. 2 (2013): 39-46. 
daring dan kuantitas pemberian tugas kuliah. Berdasarkan referensi yang ditemukan, terdapat sejumlah faktor yang dapat mempengaruhi kepuasan belajar mahasiswa, seperti: profesionalisme dosen, kinerja dosen, kemudahan akses informasi akademik, layanan mengajar, sarana prasarana, dan kenyamanan mahasiswa dalam proses perkuliahan di perguruan tinggi.

\section{Referensi}

Biasutti, M., and E. D. Heba. 'Using Wiki in Teacher Education: Impact on Knowledge Management Processes and Student Satisfaction'. Computers E Education 59, no. 3 (2012): 861-72.

Colquitt, Jason, Jeffery A. Lepine, Michael J. Wesson, and Ian Robert Gellatly. Organizational Behavior: Improving Performance and Commitment in the Workplace. Vol. 375. McGraw-Hill Irwin New York, NY, 2011.

Hakim, Mujibul, and Aria Mulyapradana. 'Pengaruh Penggunaan Media Daring dan Motivasi Belajar terhadap Kepuasan Mahasiswa Pada Saat Pandemik Covid-19'. Widya Cipta: Jurnal Sekretari Dan Manajemen 4, no. 2 (2020): 154-60.

Isrofiyah, Safi'. 'Efektivitas Penggunaan Media WA (Whatsapp) Pada Pembelajaran dengan Model Problem Posing Terhadap Motivasi Dan Hasil Belajar Kognitif Dalam Materi Stoikiometri Kelas X.' Disertasi Dan Tesis Program Pascasarjana UM, 2017.

Juhji, Juhji. Profesi Pendidik Dan Tenaga Kependidikan. Serang: Pusat Penelitian dan Penerbitan LP2M IAIN Sultan Maulana Hasanuddin Banten, 2017.

Kheryadi, Kheryadi. "The Implementation of "Whatsapp" as a Media of English Language Teaching'. Loquen: English Studies Journal 10, no. 2 (2018): 1-14.

Nauli, Pigo. 'Perbandingan Metoda Pembelajaran Akuntansi Pengantar antara Metoda Konvensional dan Metoda Berbasis Matematika Terhadap Prestasi dan Kepuasan Belajar'. Simposium Nasional Akuntansi XIV Aceh, 2011.

Opdecam, Evelien, and Patricia Everaert. 'Improving Student Satisfaction in a First-Year Undergraduate Accounting Course by Team Learning'. Issues in Accounting Education 27, no. 1 (2012): 53-82. 
Putrielis, Ekwanis. 'Keterkaitan Penggunaan Moving Class dengan Motivasi Belajar dan Dampaknya terhadap Kepuasan Belajar Ekonomi Siswa Man 2 Model Pekanbaru'. PEKBIS (Jurnal Pendidikan Ekonomi Dan Bisnis) 9, no. 2 (2017): 125-39.

Rahmawati, Diana. 'Analisis Faktor-Faktor Yang Mempengaruhi Kepuasan Mahasiswa'. Jurnal Economia 9, no. 1 (2013): 52-65.

Sabriani, Sitti. 'Penerapan Pemberian Tugas Terstruktur Disertai Umpan Balik Pada Pembelajaran Langsung Untuk Meningkatkan Motivasi dan Hasil Belajar Siswa (Studi Pada Materi Pokok Struktur Atom Kelas X6 SMA Negeri 3 Watampone).' Chemica: Jurnal Ilmiah Kimia Dan Pendidikan Kimia 13, no. 2 (2013): 39-46.

Siregar, Rini Kesuma, Nusaimah Harahap, and Lisa Fitri Meidipa. 'Efektifitas Penggunaan Whatsapp Untuk Mengurangi Prokrastinasi Akademik Mahasiswa Bahasa Inggris di Universitas Graha Nusantara'. Jurnal LPPM 9, no. 3 (2019).

Sugandi, Lianna. 'Pengaruh Teknologi Informasi Untuk Meningkatkan Pelayanan dalam Proses Belajar Mengajar'. ComTech: Computer, Mathematics and Engineering Applications 5, no. 2 (2014): 939-53.

Sulistyan, Riza Bahtiar, Hafid Aditya Pradesa, and Kasno Kasim. 'Peran Mediasi Kepuasan Dalam Pengaruh Kualitas Pelayanan Dan Citra Institusi Terhadap Retensi Mahasiswa (Studi Pada Mahasiswa Perguruan Tinggi Di Lumajang)'. WIGA-Jurnal Penelitian Ilmu Ekonomi 7, no. 2 (2017): 77-87.

Surani, Dewi, and A Chaerudin. 'Pemanfaatan Media Whatsapp Grouping dalam Peningkatan Kemampuan Bahasa Inggris Ekonomi Mahasiswa Fakultas Ekonomi dan Bisnis'. Tarbawi: Jurnal Keilmuan Manajemen Pendidikan 5, no. 02 (2019): 155-72.

Surya, M. Psikologi Pembelajaran Dan Pengajaran. Bandung: Pustaka Bani Quraisy, 2014.

Susanto, H. 'Pengaruh Layanan Akademik terhadap Kepuasan Mahasiswa Program Pascasarjana Universitas Terbuka Pada Unit Program Belajar Jarak Jauh (UPBJJ) Mataram'. Jurnal Pendidikan Terbuka Dan Jarak Jauh 15, no. 2 (2014): 88-98.

Suti, Marus. 'Strategi Peningkatan Mutu di Era Otonomi Pendidikan'. Jurnal Medtek 3, no. 2 (2011): 1-6. 
Syarifudin, Albitar Septian. 'Impelementasi Pembelajaran Daring untuk Meningkatkan Mutu Pendidikan Sebagai Dampak Diterapkannya Social Distancing'. Jurnal Pendidikan Bahasa Dan Sastra Indonesia Metalingua 5, no. 1 (2020): 31-34.

Yensy, N. A. 'Efektifitas Pembelajaran Statistika Matematika melalui Media Whatsapp Group Ditinjau dari Hasil Belajar Mahasiswa (Masa Pandemik Covid 19)'. Jurnal Pendidikan Matematika Raflesia 5, no. 2 (2020): 65-74.

Zineldin, M., H. C. Akdag, and V. Vasicheva. 'Assessing Quality in Higher Education: New Criteria for Evaluating Students' Satisfaction'. Quality in Higher Education 17, no. 2 (2011): 23143. 